\title{
FAKTOR TINGKAT PENDIDIKAN DAN PENGHASILAN TERHADAP PERSEPSI MUTU PELAYANAN KESEHATAN DI PUSKESMAS
}

\author{
Abi Muhlisin ${ }^{1}$, Supratman, Ida Listiani ${ }^{2}$ \\ FIK UMS Surakarta ${ }^{1,2}$ \\ Email : abi el@,yahoo.com
}

\begin{abstract}
Perception has an important role in order to valuing quality of service since good perception from the patients about the quality of service will affecting their satisfaction and will create positive image about health services. The purpose of this research is to configuring the correlational realtionship between patient's educational degree and income to the patient's perception about quality of health services in Puskesmas. It's a correlational research conducted by cross sectional approach. There were about 100 respondents taken by accidental sampling who were taking a part in this study. The data collected through a questionnaire and analysed by univariate analysis and bivariate analysis using chi square test. Statistical analysis show p value 0,008 for educational degree and patient's perception and $p$ value 0,000 for patient's income and their perception. It can be conclude that there are significant correlationship between educational degree and income to patient's perception about health quality service in Puskesmas. Improving training to the health care personnel according to their profession, as an effort to improving their abilty, skill and knowledge, will bring an impact to a better health quality service.
\end{abstract}

Key words : quality service, income, educational degree, perseption

\section{PENDAHULUAN}

Manusia adalah faktor kunci keberhasilan dari suatu pembangunan. Untuk menciptakan manusia yang berkualitas diperlukan suatu derajat kesehatan manusia yang prima sehingga dalam hal ini di perlukan pembangunan kesehatan. Pembangunan kesehatan merupakan upaya yang dilaksanakan oleh semua komponen bangsa yang bertujuan untuk meningkatkan kesadaran, kemauan, dan kemampuan hidup sehat bagi setiap orang agar terwujud derajat kesehatan masyarakat yang setinggi-tingginya. Dalam rangka mencapai tujuan tersebut, pembangunan kesehatan dilaksanakan secara terarah, berkesinambungan dan realistis sesuai dengan pentahapannya (Depkes RI, 2009).

Puskesmas merupakan salah satu sarana pelayanan kesehatan yang menjadi andalan atau tolak ukur pembangunan kesehatan, sarana peran serta masyarakat, dan sebagai pusat pelayanan pertama yang menyeluruh dari suatu wilayah (Alamsyah, 2011). Adanya bentuk pelayanan kesehatan yang diberikan oleh Puskesmas ini diharapkan pasien akan dapat memberikan penilaian tersendiri 
terhadap puskesmas pembangunan kesehatan dilaksanakan secara terarah, berkesinambungan dan realistis sesuai dengan pentahapannya (Depkes RI, 2009).

Puskesmas merupakan salah satu sarana pelayanan kesehatan yang menjadi andalan atau tolak ukur pembangunan kesehatan, sarana peran serta masyarakat, dan sebagai pusat pelayanan pertama yang menyeluruh dari suatu wilayah (Alamsyah, 2011). Adanya bentuk pelayanan kesehatan yang diberikan oleh Puskesmas ini diharapkan pasien akan dapat memberikan penilaian tersendiri terhadap puskesmas tersebut (Pohan, 2015).

Persepsi terhadap pelayanan di mulai dari kebutuhan pasien, hal ini berarti pelayanan yang baik bukan dilihat dari penyedia jasa layanan, namun dari sudut pandang pasien. Faktor yang mempengaruhi persepsi pasien terhadap pelayanan kesehatan itu sendiri antara lain umur, jenis kelamin, tingkat pendidikan, pekerjaan, penghasilan, budaya, lingkungan fisik, kepribadian dan pengalaman hidup pasien (Jacobalis, 2000).

Persepsi mempunyai peran yang sangat penting dalam menilai suatu mutu pelayanan kesehatan, karena berdasarkan persepsi yang baik dari pasien terhadap mutu pelayanan akan dapat mempengaruhi kepuasan pasien dan menimbulkan image yang positif kepada pelayanan kesehatan tersebut (Kotler, 2007).

Sebagai pusat pelayanan kesehatan strata pertama di wilayah kerjanya, puskesmas wajib menyelenggarakan pelayanan kesehatan secara bermutu, terjangkau, adil dan merata. Mutu dapat diartikan sebagai derajat kesempurnaan dalam pelayanan kesehatan. Pentingnya meningkatkan mutu pelayanan puskesmas adalah untuk membangun persahabatan yang mendorong hubungan dengan pasien sehingga puskesmas tidak ditinggalkan oleh pasien (Azwar 2010).

Berdasarkan rekapitulasi laporan ikhtisar kunjungan rawat jalan puskesmas Kabupaten Sukoharjo, Puskesmas Baki adalah puskesmas dengan kunjungan pasien rawat jalan terendah tahun 2015 (Dinkes Sukoharjo, 2015). Jumlah kunjungan rawat jalan tahun 2015 mengalami penurunan dibandingkan dengan tahun 2014 yaitu sebesar 58.787 menjadi 58.331 pasien.

Hasil wawancara tidak terstruktur, 4 dari 10 pasien yang berobat menggunakan pembayaran umum (tidak menggunakan asuransi kesehatan) dan pengguna BPJS Non-PBI mengatakan kurang puas terhadap pelayanan Puskesmas Baki. Sedangkan 6 dari 10 pasien yang menggunakan BPJS PBI mengatakan puas dengan pelayanan Puskesmas Baki dimana pelayanannya sudah baik. Adanya perbedaan persepsi pasien tersebut, diduga karena perbedaan tingkat pendidikan dan status ekonomi masyarakatnya.

Menurut Nursalam (2011) dengan bertambah baiknya tingkat pendidikan dan sosial ekonomi penduduk, tuntutan masyarakat terhadap mutu pelayanan kesehatan merupakan sebuah elemen penting yang tidak dapat terpisahkan. Jacobalis (2000) menyatakan bahwa tingkat pendidikan dan penghasilan 
merupakan variabel yang mempengaruhi persepsi pasien terhadap mutu pelayanan kesehatan.

\section{METODE PENELITIAN}

Penelitian ini adalah penelitian korelasional dengan pendekatan cross sectional. Penelitian dilakukan di Puskesmas Baki Kabupaten Sukoharjo pada tanggal 6-11 Januari 2017. Populasi dalam penelitian ini adalah pasien rawat jalan di Puskesmas Baki tahun 2017. Sampel dalam penelitian ini adalah 100 pasien dengan Teknik pengambilan sampel yang digunakan adalah accidental sampling dimana subjek penelitian diambil secara kebetulan bertemu dan sesuai dengan kriteria yang telah ditentukan peneliti (Notoatmodjo, 2012). Kriteria sampel yang digunakan adalah pasien yang menggunakan pelayanan rawat jalan Puskesmas Baki Sukoharjo dan pasien yang berusia 17 - 59 tahun yang memiliki penghasilan perbulan yang berjumlah 98 dan sampel dibulatkan menjadi 100 responden.

\section{HASIL DAN PEMBAHASAN}

Tabel 1. DistribusiDemografi Pasien Rawat Jalan

\begin{tabular}{|c|c|c|c|}
\hline No & Karakteristik & Frekuensi & $(\%)$ \\
\hline \multirow[t]{5}{*}{1} & Umur (th) & & \\
\hline & a. $17-25$ & 24 & 24 \\
\hline & b. $26-45$ & 42 & 42 \\
\hline & c. $46-59$ & 34 & 34 \\
\hline & Total & 100 & 100 \\
\hline \multirow[t]{4}{*}{2} & Jenis Kelamin & & \\
\hline & a. Laki-laki & 39 & 39 \\
\hline & b. Perempuan & 61 & 61 \\
\hline & Total & 100 & 100 \\
\hline \multirow[t]{5}{*}{3.} & Pekerjaan & & \\
\hline & a. Buruh & 30 & 30 \\
\hline & b. Wiraswasta & 55 & 55 \\
\hline & c. PNS & 15 & 15 \\
\hline & Total & 100 & 100 \\
\hline \multirow[t]{5}{*}{4.} & Tingkat Pendidikan & & \\
\hline & a. Rendah (SD-SMP) & 31 & 31 \\
\hline & b. Menengah (SMA) & 40 & 40 \\
\hline & c. Tinggi (Perguruan Tinggi) & 29 & 29 \\
\hline & Total & 100 & 100 \\
\hline \multirow[t]{4}{*}{5.} & Penghasilan & & \\
\hline & a. Rendah (<UMR) & 55 & 55 \\
\hline & b. Tinggi $(=/>$ UMR $)$ & 45 & 45 \\
\hline & Total & 100 & 100 \\
\hline \multirow[t]{4}{*}{6.} & Persepsi & & \\
\hline & a. Baik & 56 & 56 \\
\hline & b. Kurang Baik & 44 & 44 \\
\hline & Total & 100 & 100 \\
\hline
\end{tabular}

Dari tabel 1 dapat dilihat bahwa karakteristik umur responden di Puskesmas Baki menunjukkan responden sebagian besar berumur 26-45 tahun yaitu sebanyak 
42 responden (42\%), berumur 46-59 tahun sebanyak 34 responden (34\%), dan berumur 17-25 sebanyak 24 responden (24\%). Karakteristik jenis kelamin responden di Puskesmas Baki menunjukkan jenis kelamin responden sebagian besar adalah perempuan yaitu sebanyak 61 responden (61\%), dan berjenis kelamin laki-laki sebanyak 39 responden (39\%). Karakeristik pekerjaan responden di Puskesmas Baki menunjukkan pekerjaan responden sebagian besar adalah wiraswasta yaitu sebanyak 55 responden (55\%), buruh sebanyak 30 responden (30\%), dan PNS sebanyak 15 responden (15\%). Karakteristik tingkat pendidikan responden di Puskesmas Baki menunjukkan tingkat pendidikan responden sebagian besar berpendidikan menengah (SMA) yaitu sebanyak 40 responden (40\%), berpendidikan rendah (SD-SMP) sebanyak 31 responden (31\%), dan berpendidikan tinggi (Perguruan Tinggi) sebanyak 29 responden (29\%). Penghasilan responden di Puskesmas Baki menunjukkan penghasilan responden sebagian besar berpenghasilan tinggi (lebih dari UMR Rp.1.513.000,00) yaitu sebanyak 55 responden (55\%), dan berpenghasilan rendah (kurang dari UMR Rp.1.513.000,00) sebanyak 45 responden (45\%).

Dari tabel 1 dapat diketahui bahwa sebagian besar responden berpersepsi bahwa pelayanan kesehatan di Puskesmas Baki dalam kategori baik yaitu sebanyak 56 responden (56\%), dan 44 responden (44\%) lainnya berpersepsi bahwa pelayanan kesehatan di Puskesmas Baki kurang baik.

Dalam pengujian hipotesis, analisis yang digunakan dalam penelitian ini adalah analisis chi-square. Adapun hasil analisis untuk hubungan masing-masing variabel adalah sebagai berikut ini:

Tabel 2. Hubungan Tingkat Pendidikan Pasien dengan Persepsi Pasien Tentang Mutu Pelayanan Kesehatan

\begin{tabular}{llll}
\hline Tingkat pendidikan & Persepsi & & Total \\
& Baik & Kurang Baik & \\
\hline Rendah & 23 & 8 & 31 \\
Menengah & 23 & 17 & 40 \\
Tinggi & 10 & 19 & 29 \\
\hline Total & 56 & 44 & 100 \\
\hline$X^{2}=9,650$ & & $p=0,008$ & \\
\hline
\end{tabular}

Dari tabel 2 dapat diketahui analisis uji Chi-Square diperoleh nilai p-value 0,008 dimana tingkat signifikansi kurang dari 0,05, sehingga kesimpulan dari hasil uji adalah terdapat hubungan yang signifikan antara tingkat pendidikan pasien dengan persepsi pasien tentang mutu pelayanan kesehatan. 
Tabel3. Hubungan Penghasilan Pasien dengan Persepsi Pasien Tentang Mutu Pelayanan Kesehatan

\begin{tabular}{llll}
\hline Penghasilan & Persepsi & Total \\
& Baik & Kurang Baik & \\
\hline Rendah & 39 & 6 & 45 \\
Tinggi & 17 & 38 & 55 \\
\hline Total & 56 & 44 & 100 \\
\hline$X^{2}=31,228$ & & $p=0,000$ & \\
\hline
\end{tabular}

Dari tabel 2 dapat diketahui analisis uji Chi-Square diperoleh nilai $p$-value 0,000 dimana tingkat signifikansi kurang dari 0,05, sehingga kesimpulan dari hasil uji adalah terdapat hubungan yang signifikan antara penghasilan pasien dengan persepsi pasien tentang mutu pelayanan kesehatan.

Hasil perhitungan chi-square didapatkan nilai p-value 0,008 dimana tingkat signifikansi kurang dari 0,05 . Hasil tersebut membuktikan bahwa memang ada hubungan yang signifikan antara tingkat pendidikan dengan persepsi pasien tentang mutu pelayanan kesehatan di Puskesmas Baki.

Hasil penelitian ini didukung oleh penelitian Budiman dan Herlina (2010) di Puskesmas Tanjungsari Bogor, dimana pendidikan mempunyai hubungan yang signifikan dengan kepuasan pasien dengan nilai $p$-value $0,000(<0,05)$. Penelitian ini sejalan pula dengan penelitian Laith (2011) di Jordania, dengan hasil bahwa tingkat pendidikan mempengaruhi persepsi pasien terhadap kalitas pelayanan. Penelitian lain yang sejalan yaitu penelitian Pinar Yesil (2015) di Turki, yang membuktikan bahwa ada hubungan yang signifikan antara tingkat pendidikan dengan persepsi pasien, dimana pasien dengan pendidikan rendah memiliki kepuasan yang tinggi dibandingkan dengan pasien dengan pendidikan tinggi. Hal ini membuktikan sebagaimana yang diterangkan oleh Notoatmodjo (2005), bahwa tingkat pendidikan merupakan salah satu faktor yang mempengaruhi harapan dan persepsi seseorang terhadap pelayanan kesehatan. Semakin tinggi pendidikan seseorang maka akan semakin mengerti tentang kesehatan. Seseorang dengan pendidikan lebih rendah cenderung mempersepsikan pelayanan baik dibandingkan dengan yang berpendidikan tinggi (Tjiptono, 2007).

Menurut Jacobalis (2000), tingkat pendidikan dapat mempengaruhi pola pikir rasional dan irasional seseorang dalam mengambil keputusan, menggunakan, atau memanfaatkan suatu pelayanan kesehatan. Seseorang dengan pendidikan rendah memiliki kecenderungan inkonsistensi persepsi yang tinggi (tidak tetap pendirian), mudah dipengaruhi dibandingkan dengan seseorang dengan latar belakang pendidikan tinggi. Pengetahuan dan harapan seseorang terhadap pelayanan akan meningkat ketika tingkat pendidikan mereka semakin tinggi, sehingga tingkat kepuasan seseorang dengan pendidikan tinggi akan menurun ketika harapan tidak terpenuhi (Yurumezoglu, 2007). 
Oleh karena itu, smakin tinggi tingkat pendidikan pasien maka semakin tinggi pula harapan dan tuntutannya terhadap pelayanan kesehata. Seseorang dengan pendidikan tinggi akan memiliki pengetahuan yang lebih dan semakin mengarti arti kesehatannya, sehingga semakin kritis terhadap pelayanan kesehatan yang dibutuhkannya, hal ini akan mempengaruhi persepsinya terhadap pelayanan kesehatan yang diterimanya. Sedangkan pasien yang berpendidikan rendah, cenderung memiliki pengetahuan yang kurang dan mudah dipengaruhi di bandingkan pasien dengan pendidikan tinggi, sehingga pasien dengan pendidikan rendah cenderung menerima pelayanan kesehatan tanpa tuntutan yang lebih, hal ini akan mempengaruhi persepsinya terhadap pelayanan kesehatan yang diterimanya dimana pasien dengan pendidikan rendah akan memiliki persepsi yang tinggi atau baik terhadap pelyanan yang diterimanya.

Namun demikian, hasil penelitian ini tidak sejalan dengan penelitian Azlika (2015) di Manado, yang menunjukkan hasil tidak ada hubungan antara tingkat pendidikan dengan kepuasan pasien dengan $p$-value $0,750(>0,05)$. Oleh karena itu, persepsi setiap orang terhadap pelayanan kesehatan sangatlah bervariasi, dimana persepsi ini tidak hanya dipengaruhi oleh pendidikan saja, melainkan dapat pula dipengaruhi faktor-faktor lain yang mungkin dapat mempengaruhi persepsi seseorang terhadap pelayanan kesehatan.

Hasil perhitungan pada tabel 3 chi-square didapatkan nilai $p$-value 0,000 dimana tingkat signifikansi kurang dari 0,05. Hasil tersebut membuktikan bahwa memang ada hubungan yang signifikan antara penghasilan dengan persepsi pasien tentang mutu pelayanan kesehatan di Puskesmas Baki.

Hasil penelitian ini didukung oleh penelitian Putu (2016) di Sleman Yogyakarta, dengan hasil ada hubungan yang signifikan antara penghasilan dengan kepuasan pasien. Penelitian lain yang mendukung adalah penelitian Laith (2011) di Jordania, yang menunjukkan bahwa penghasilan mempengaruhi persepsi pasien terhadap kalitas pelayanan. Selain itu, penelitian yang sejalan pula dengan penelitian ini adalah penelitian Pinar Yesil (2015) di Turki, yang membuktikan bahwa ada hubungan yang signifikan antara penghasilan pasien dengan persepsi pasien.

Hal ini membuktikan sebagaimana yang diterangkan oleh Jacobalis (2000), bahwa penghasilan seseorang merupakan salah satu faktor yang mempengaruhi persepsi seseorang. Seseorang dengan penghasilan tinggi memiliki tuntutan dan harapan yang lebih besar terhadap pelayanan kesehatan yang dibutuhkannya karena seseorang dengan penghasilan tinggi mampu secara finansial, sedangkan responden dengan penghasilan rendah umumnya lebih tergantung pada fasilitas kesehatan yang lebih murah sehingga dengan penghasilan yang dimiliki tetap dapat menerima pelayanan kesehatan yang terjangkau. Penghasilan pasien menentukan kepuasan yang dirasakan karena bila pendapatan yang diperoleh kecil cenderung pelayanan kesehatan yang diterima lebih sedikit atau minimal (Barata, 2006). Menurut 
Kirilmaz (2013), pasien dengan penghasilan yang baik akan dapat memenuhi beberapa kebutuhan mereka dengan lebih baik dibandingkan mereka yang berpenghasilan rendah, sehingga orang yang berpenghasilan rendah kan memiliki harapan yang kurang terhadap pelayanan kesehatan.

Oleh karena itu, seseorang dengan penghasilan tinggi akan memiliki tuntutan dan harapan yang tinggi terhadap pelayanan kesehatan dibandingkan dengan seseorang yang berpenghasilan rendah. Hal ini dikarenakan seseorang dengan penghasilan tinggi akan merasa mampu secara finansial dalam pemenuhan kebutuhannya akan pelayanan kesehatan, sehingga orang yang berpenghasilan tinggi cenderung akan menggunakan penghasilannya untuk membayar pelayanan yang dianggapnya memenuhi harapan dan memberikan kepuasan kepadanya. Sedangkan seseorang dengan penghasilan rendah cenderung bergantung pada pelayanan kesehatan yang murah sehingga dengan peghasilan yang dimilikinya akan tetap dapat menerima pelayanan yang dianggap terjangkau dari segi biaya tanpa tuntutan dan harapan yang lebih.

Namun demikian, hasil penelitian ini tidak sejalan dengan penelitian Mutu (2009), yang menunjukkan tidak ada hubungan antara penghasilan dengan persepsi pelanggan terhadap pelayanana puskesmas Kotamobagu. penelitian lain yang tidak sejalan adalah penelitian Subait (2016) di Saudi Arabia, yang menunjukkan hasil bahwa tingkat pendapatan pasien tidak mempengaruhi kepuasan pasien. Oleh karena itu, persepsi seseorang tidak hanya dipengaruhi oleh penghasilan saja, melainkan dapat pula dipengaruhi faktor-faktor lain yang mungkin dapat mempengaruhi persepsi seseorang terhadap pelayanan kesehatan.

\section{KESIMPULAN DAN SARAN}

Berdasarkan hasil penelitian dari 100 responden, 23\% berpendidikan rendah, $23 \%$ berpendidikan menengah, dan $10 \%$ berpendidikan tinggi serta $39 \%$ berpenghasilan rendah dan $17 \%$ berpenghasilan tinggi menyatakan mutu pelayanan kesehatan di Puskesmas Baki sudah baik. Sedangkan $8 \%$ berpendidikan rendah, $17 \%$ berpendidikan menengah, dan $19 \%$ berpendidikan tinggi serta $6 \%$ berpenghasilan rendah dan $38 \%$ berpenghasilan tinggi menyatakan mutu pelayanan kesehatan di Puskesmas Baki masih kurang baik. Sehingga dapat disimpulkan bahwa dari 100 responden, 56\% berpersepsi bahwa mutu pelayanan kesehatan di Puskesmas Baki dalam kategori baik, dan $44 \%$ berpersepsi mutu pelayanan kesehatan di Puskesmas Baki kurang baik.

Berdasarkan uji statistik membuktikan bahwa ada hubungan yang signifikan antara tingkat pendidikan dengan persepsi pasien tentang mutu pelayanan kesehatan di Puskesmas Baki Sukoharjo dan antara penghasilan pasien dengan persepsi pasien tentang mutu pelayanan kesehatan di Puskesmas Baki Sukoharjo.

Dari hasil penelitian tersebut, peneliti menyarankan supaya : 
1. Perlu mengadakan dan meningkatkan pelatihan petugas sesuai dengan profesi, sebagai upaya untuk meningkatkan kemampuan, keterampilan dan pengetahuan petugasnya yang akan berdampak pada peningkatan mutu pelayanan kesehatan.

2. Perlu meningkatkan dan mempertahankan sikap disiplin kepada petugas terhadap aturan yang berlaku sehingga dapat meningkatkan mutu pelayanan kesehatan.

3. Perlu penambahan jumlah petugas, pemeliharaan fasilitas secara berkala, serta sosialisasi terkait SPO dan standar waktu tunggu.

4. Perlu meningkatkan kualitas pelayanan dengan meningkatkan kemampuan, keterampilan dan pengetahuannya dengan mengikuti pelatihan-pelatihan seseai profesi atau mengikuti pendidikan berkelanjutan.

5. Perlu lebih memahami kebutuhan pasien akan pelayanan kesehatan sehingga dapat memberikan pelayanan sesuai dengan kebutuhan dan harapan pasien.

\section{DAFTAR PUSTAKA}

Alamsyah, D. (2011). Manajemen Pelayanan Kesehatan. Yogyakarta: Nuha Medika.

Azlika, M. A., Adisti, A. R., Febi, K. K.(2015). Hubungan antara Mutu Pelayanan Perawat dan Tingkat Pendidikan dengan Kepuasan Pasien Peserta Badan Penyelenggaraan Jaminan Sosial (BPJS) Kesehatan di Ruang Rawat Inap Rumah Sakit Islam (RSI) Siti Maryam Kota Manado.Jurnal Ilmiah FarmasiUNSRAT, Volume.4, No. 4.

Azwar, A. (2010). Pengantar Administrasi Kesehatan. Tangerang: Binaputra Aksara.

Christasani, P. D., \& Satibi, S. (2016). Kajian Faktor Demografi Terhadap Kepuasan Pasien Jaminan Kesehatan Nasional pada Fasilitas Kesehatan Tingkat Pertama. Jurnal Farmasi Sains dan Komunitas, 13(1), 28-34.

Departemen Kesehatan Republik Indonesia. (2009). Sistem Kesehatan Nasional. Jakarta.

Dinas Kesehatan Kabupaten Sukoharjo. (2016). Rekapitulasi Laporan Ikhtisar Kunjungan Rawat Jalan Puskesmas Kabupaten Sukoharjo.

Jacobalis, S. (2000). Kumpulan Tulisan Terpilih Tentang Rumah Sakit Indonesia dalam Dinamika Sejarah, Transformasi, Globalisasi dan Krisis Nasional. Jakarta: Yayasan Penerbit IDI. 
Kirllmaz H. (2013). An Investigation of Factors Affecting Patient Satisfaction in the Framework Of Performance Management: a Field Study on Polyclinic Patients. Journal of Acıbadem University Health Sciences 4, 11-21.

Kotler, P. (2007). Manajemen Pemasaran: Analisis Perencanaan, Implementasi, dan Kontrol. Edisi ke enam. Jakarta: Penerbit Erlangga.

Laith, A., \& Alkaa'ida, F. (2011). The mediating effect of patient satisfaction in the patients' perceptions of healthcare quality-patient trust relationship. International Journal of Marketing Studies, 3(1), 103-127.

Levy, P.S., Lemeshow, S. (1997). Sampling of Populations: Methods and Applications, 3 rded. New York: Wiley-Interscience.

Mokoginta, M.B., Sugihen, B.G., Susanto, D., Asngari, P.S. (2009). Karakteristik Pelanggan dan Persepsi Pelanggan Terhadap Pelayanan Puskesmas Kota Kotamobagu dan Kabupaten Bolaang Margondoe Utara, Provinsi Sulawesi Utara. Jurnal Penyuluhan, Volume 5, Nomor1, Maret 2009.

Notoatmodjo, S. (2005). Metodelogi Penelitian Kesehatan. Jakarta: Rineka Cipta. (2012). Metodelogi Penelitian Kesehatan. Jakarta: Rineka Cipta.

Nursalam. (2013). Metodologi Penelitian Ilmu Keperawatan, Edisi3. Jakarta: Salemba Medika.

Pinar, Y., Oztunc, G., Zehra, E., Gulsah, T., \& Kose, I. (2015). An Investigation of Patients' Perceptions of Nursing Care: Case of Intensive Care. International Journal of Caring Sciences,8(2), 412.

Pohan, I.S. (2015). Jaminan Mutu Pelayanan Kesehata. Jakarta: EGC.

Subait AA, Ali A, Alsammahi O, Aleesa M, Alkashan S, Alsalem M, et al. (2016). Perception and Level of Satisfaction of Patients Seeking Dental Care; A Cross-Sectional Study in a Major Healthcare Center in Saudi Arabia. Jurnal Dent \& Oral Disord, 2(4): 1021.

Walgito, B. (2010). Pengantar Psikologi Umum. Yogyakarta: Penerbit Andi 